\title{
A Brief History of Mitochondrial Pathologies
}

\author{
Salvatore DiMauro \\ Department of Neurology, Columbia University Medical Center, New York, NY 10032, USA; \\ sd12@cumc.columbia.edu
}

Received: 8 July 2019; Accepted: 23 October 2019; Published: 12 November 2019

\begin{abstract}
The history of "mitochondrial pathologies", namely genetic pathologies affecting mitochondrial metabolism because of mutations in nuclear DNA-encoded genes for proteins active inside mitochondria or mutations in mitochondrial DNA-encoded genes, began in 1988. In that year, two different groups of researchers discovered, respectively, large-scale single deletions of mitochondrial DNA (mtDNA) in muscle biopsies from patients with "mitochondrial myopathies" and a point mutation in the mtDNA gene for subunit 4 of NADH dehydrogenase (MTND4), associated with maternally inherited Leber's hereditary optic neuropathy (LHON). Henceforth, a novel conceptual "mitochondrial genetics", separate from mendelian genetics, arose, based on three features of mtDNA: (1) polyplasmy; (2) maternal inheritance; and (3) mitotic segregation. Diagnosis of mtDNA-related diseases became possible through genetic analysis and experimental approaches involving histochemical staining of muscle or brain sections, single-fiber polymerase chain reaction (PCR) of mtDNA, and the creation of patient-derived "cybrid" (cytoplasmic hybrid) immortal fibroblast cell lines. The availability of the above-mentioned techniques along with the novel sensitivity of clinicians to such disorders led to the characterization of a constantly growing number of pathologies. Here is traced a brief historical perspective on the discovery of autonomous pathogenic mtDNA mutations and on the related mendelian pathology altering mtDNA integrity.
\end{abstract}

Keywords: mitochondrial pathologies; mtDNA mutations; mendelian and maternal inheritance

\section{Introduction}

Two great discoveries were made in 1988 by two famous researchers, Anita Harding at the Department of Clinical Neurology, Institute of Neurology, Queens Square, London, UK [1], and Doug Wallace at Emory University, Atlanta, GA [2]. The first discovery identified large-scale single deletions of mitochondrial DNA (mtDNA) in muscle biopsies from patients with "mitochondrial myopathies" while the second discovery identified a point mutation in the mtDNA gene for subunit 4 of NADH dehydrogenase complex (MTND4), associated with maternally inherited Leber's hereditary optic neuropathy (LHON) in a large American pedigree.

These two discoveries launched a new hunger for human disorders associated with mutations in the tiny mtDNA molecule: In the same year, 1988, our large group of "mitochondriacs" at Columbia University, led by Bud Rowland, clarified the genetic etiology of Kearns-Sayre's syndrome (KSS), the eponym of Anita Harding's discovery [3].

Easy sequencing of mtDNA uncovered innumerable pathogenic mutations, reaching 281 in 2018, giving rise to a morbidity map of mtDNA that illustrates the tremendous phenotypic heterogeneity of mtDNA diseases (Figure 1). 


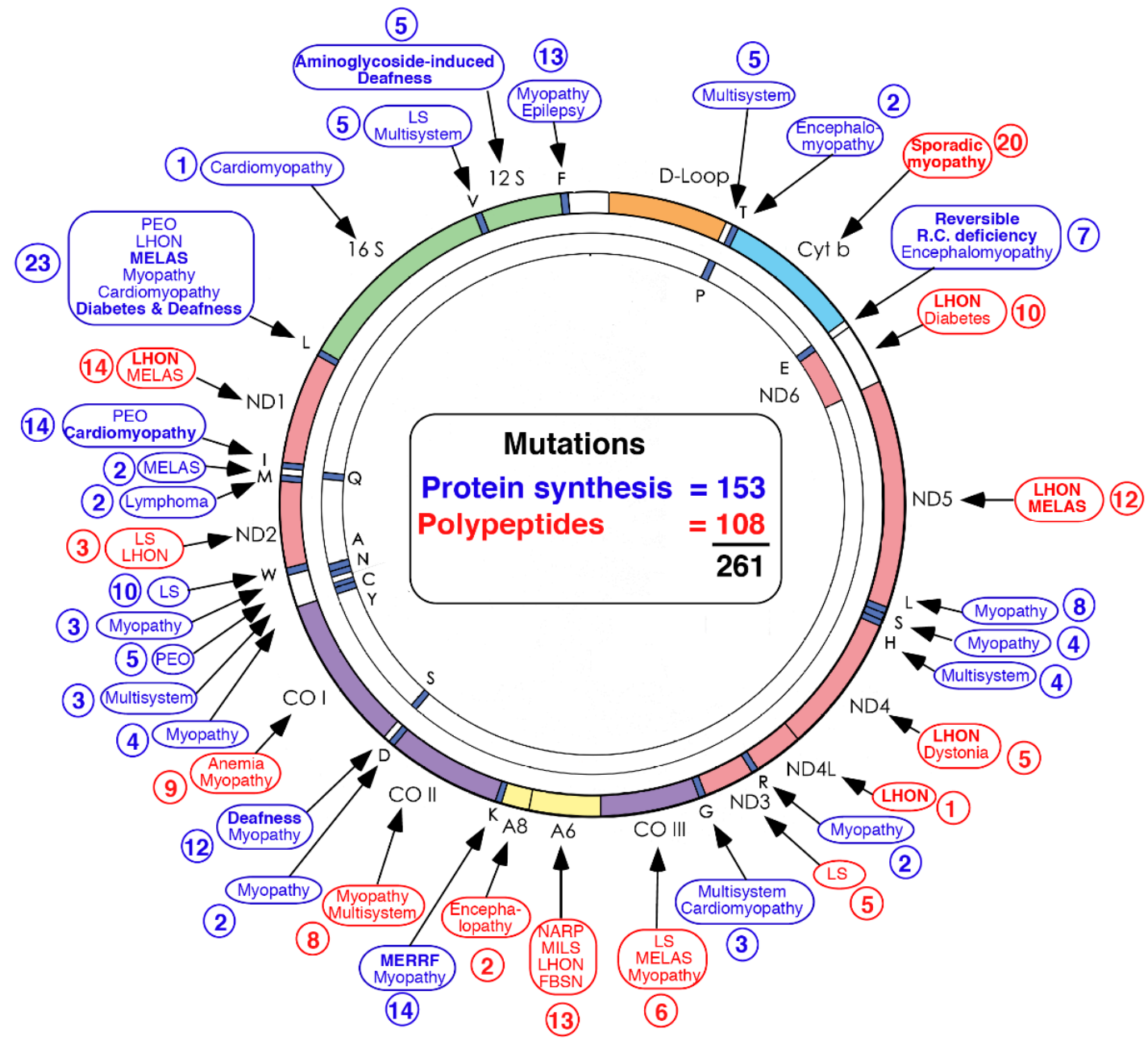

Figure 1. Morbidity map of mitochondrial DNA. Disorders caused by mutations in protein-coding genes are shown in red. Disorders caused by mutations in genes controlling protein synthesis are shown in blue.

This sensitized clinicians to a novel conceptual "mitochondrial genetics", separate from mendelian genetics, based on three principles [4,5]:

(1) Polyplasmy, homoplasmy, heteroplasmy. Each cell contains hundreds or thousands of mitochondria and each mitochondrion harbors multiple copies of mtDNA ("polyplasmy"). Normal cells have identical copies of mtDNA ("homoplasmy"), but in patients with mutations in mtDNA we find a stochastic distribution of mutant and wild-type mtDNAs ("heteroplasmy"). A crucial corollary of heteroplasmy is that a critical number of mutant mtDNAs is needed for the respiratory chain to suffer and for disease to manifest ("threshold effect").

Mitochondria are ubiquitous organelles, present in all tissues (except mature erythrocytes), explaining why mtDNA diseases can affect any or all tissues, giving rise to the most heterogeneous clinical presentations. Multisystem disorders are typical examples of mtDNA diseases, including KSS, MELAS (mitochondrial encephalomyopathy, lactic acidosis, and stroke-like episodes), MERRF (myoclonic epilepsy and ragged-red fibers), NARP/MILS (neuropathy, ataxia, retinitis pigmentosa/maternally inherited Leigh's syndrome).

However, there are rare cases in which individual tissues may be affected, for example skeletal muscle with myopathy due to mutations in the cyt $b$ gene [6].

In this situation, we postulated that the mutation load of mutant $c y t b$ was disproportionally high in skeletal muscle compared to other tissues, such as the mutation load surpassed the threshold effect. 
But typically mtDNA-related diseases are a heterogeneous group of clinical disorders. In rare instances, homoplasmic mtDNA mutations are known to cause diseases, such as LHON.

(2) Maternal inheritance. Following the evidence provided by Giles et al. [7], most pathogenic point mutations of mtDNA are transmitted maternally. An affected or unaffected mother carrying a mutant mtDNA can pass it on to all her children-boys and girls—and the disease can show, more or less severely, in all matrilinear members. Thus, it is important to collect family histories, including "soft signs" such as short stature, exercise intolerance, diabetes mellitus, or migrainous headache in maternal relatives. Family history clearly distinguishes maternally inherited mtDNA point mutations from diseases caused by large-scale single mtDNA deletions and a large survey of patients with KSS has shown the vast majority of sporadic patients [8].

A disturbing paper has recently been published [9], in which the authors question the dogma of mtDNA maternal inheritance. They convincingly showed variable heteroplasmy ( $24 \%$ to $75 \%$ ) of paternal mtDNA in three unrelated multigenerational families, examined by high-depth whole mtDNA sequencing. The implication of pathogenic paternal mtDNA mutation transmission remains to be documented, because in the same study, maternal inheritance was demonstrated to remain absolutely prevalent and in all the assayed families paternal transmission provided a limited contribution to mtDNA. Also, the hypothetical usage of paternal mtDNA transmission to reduce the consequences of maternal pathogenic mutations is far beyond. In fact, it will require the full comprehension of the mechanisms leading to elimination of paternal mtDNA in developing embryos, likely related to a still unknown autosomal dominant gene, whose mutation might prevent the usual processes.

(3) Mitotic segregation is the third rule of mitochondrial genetics. As cells, heteroplasmic for mtDNA, divide, they pass on to next generation various mutation loads of mtDNA (wild-type and mutant) and, thus, both the genotype and the phenotype may vary in time.

\section{Diagnosis of mtDNA-Related Diseases}

Three techniques have contributed valuable clues to the diagnosis of mtDNA-related diseases.

The first technique was the histochemical overlap of cytochrome c oxidase (COX) and succinate dehydrogenase (SDH) stains, introduced by my friend Eduardo Bonilla.

COX deficiency is the hallmark of mtDNA diseases, with three enzymatically active mtDNA-encoded subunits (COXI-COXIII), while SDH (complex II) is considered a marker of mitochondrial overabundance as its four subunits are entirely encoded by nuclear DNA (nDNA). In patients with mitochondrial diseases, cross sections of frozen muscle biopsies clearly show scattered COX-negative or COX-deficient fibers, which are often overstained with SDH due to abnormal compensatory mitochondrial proliferation and identified as "ragged red fibers" (RRF) with the Gomori trichrome staining. The brown stain of COX prevails over the blue stain of SDH in normal fibers while COX-negative fibers show a bright blue color ("ragged-blue fibers") and COX-deficient fibers will stain a milder bluish color [10] (Figure 2). This COX/SDH combined staining has proven diagnostically useful generally in muscle biopsies, but has been equally valuable in brain sections from patients with mtDNA-related encephalomyopathies [11].

The second — even more sensitive-technique was introduced by my great collaborator, Carlos Moraes [12], and based on PCR amplification of a novel mtDNA mutation. In particular, this method measures the relative percentages of wild-type and mutant mtDNA in COX-negative, COX-deficient, and normal-looking muscle fibers. These results give convincing clues to the pathogenicity of novel mtDNA variants. This required plucking from thick histochemical muscle sections COX-negative, COX-deficient, and normal-looking fibers and performing PCR on these tiny specimens (Figure 3). 

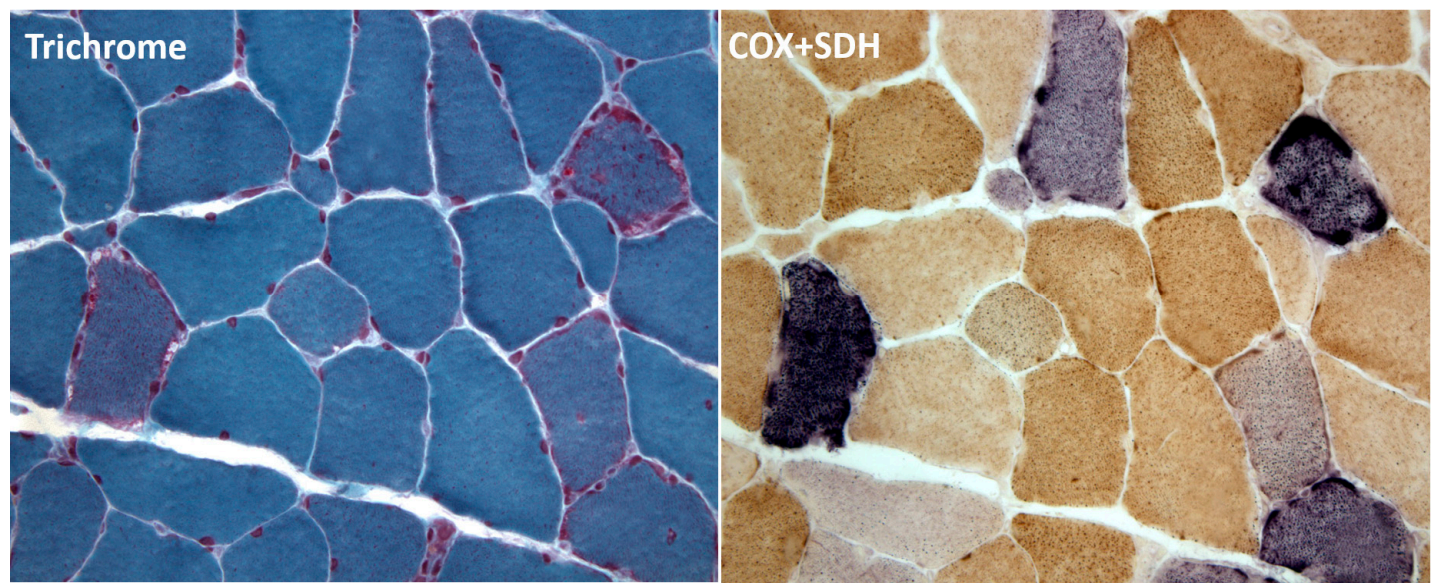

Figure 2. Cytochrome c oxidase (COX)/ succinate dehydrogenase (SDH) overlap staining in a muscle biopsy. This patient with myoclonic epilepsy and ragged-red fibers (MERRF) shows typical "ragged red fibers" (RRF) by trichrome at left. However, COX/SDH overlap staining (at right) shows COX-negative, "ragged-blue" fibers, mixed with COX-deficient bluish fibers.

\section{COX I gene mutation (G5920A)}

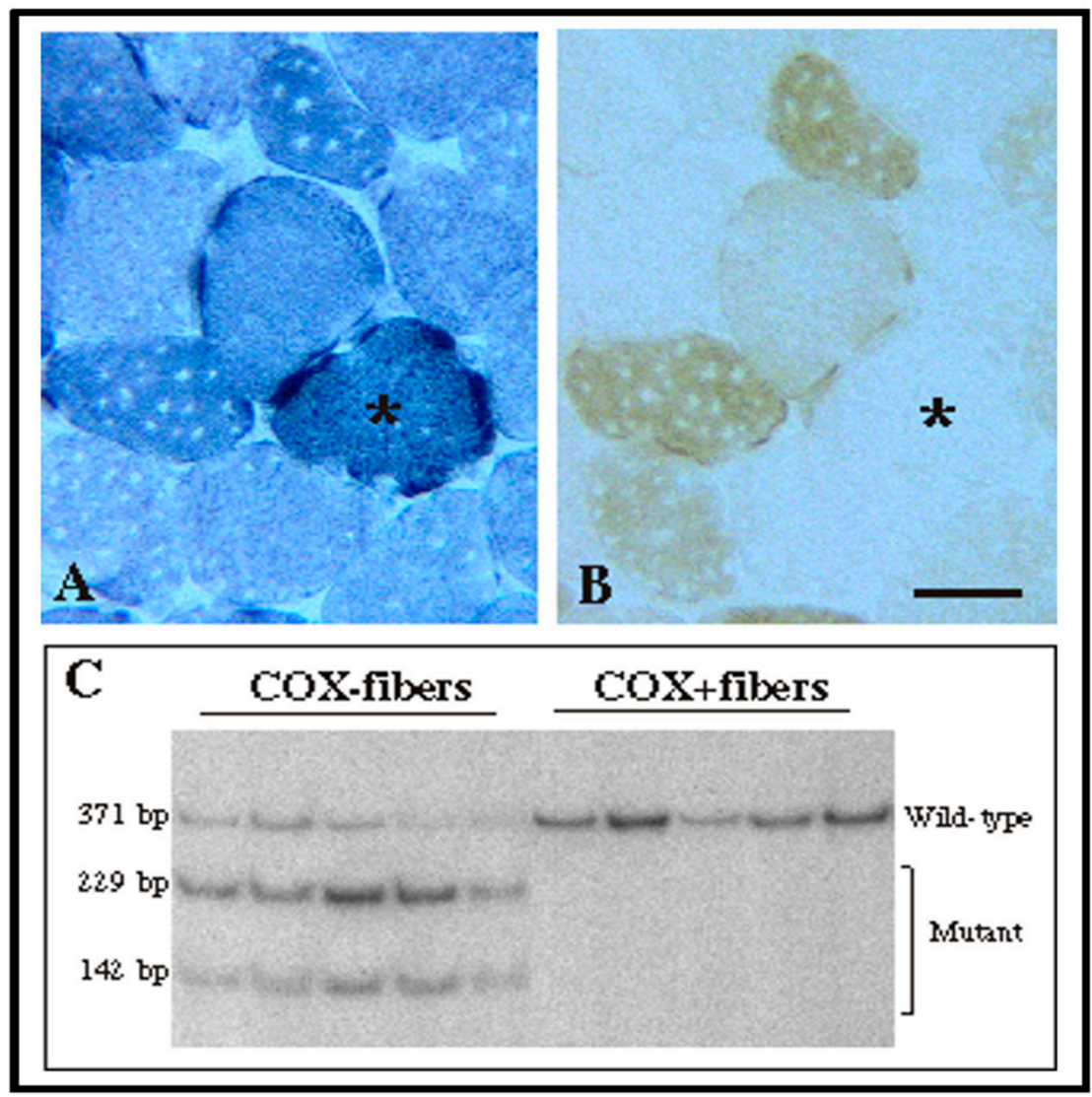

Figure 3. Evaluating the pathogenicity of a novel mtDNA mutation in single fibers by PCR. (A) Succinate dehydrogenase (SDH) staining; (B) Cytochrome c oxidase (COX) staining; (C) Analysis for a specific mtDNA mutation by PCR. In this young man with recurrent myoglobinuria, we identified a nonsense mutation in the COXI gene of mtDNA [13]. COX-negative (COX-) fibers are indicated by asterisks in A and $\mathrm{B}$. The results of the PCR analysis in single fibers clearly show the high abundance of the mutation in COX- fibers and the lack of mutation in COX+ fibers. 
The third useful technique was the creation of the so-called "cybrid" (cytoplasmic hybrid) immortal fibroblast cell lines. It consists in transferring into rho-zero cells (deprived of their mtDNA) heteroplasmic mitochondria from cultured skin fibroblasts of patients carrying mtDNA mutations [14]. These heteroplasmic or homoplasmic cybrids provided hallmark models to evaluate biochemical consequences and functional threshold effects in MELAS, MERRF, and KSS. And, to say the least, hybrid cell lines were employed in various therapeutic strategies to test different approaches to treat mtDNA-related diseases.

The autonomy of mtDNA is wide enough to explain the multiple phenotypes in mtDNA-related disorders and provides valid rules of "mitochondrial genetics" to substantiate the features of those disorders, including multisystem or monosystem, maternal or sporadic inheritance, and progressive in time.

However, in 1989, my friends Massimo Zeviani and Stefano DiDonato found several Italian families with autosomal dominant or recessive mitochondrial progressive external ophthalmoplegia (PEO) and encephalomyopathy, in whose muscle biopsies they saw RRF and multiple deletions of mtDNA [15].

The partnership between the two genomes is not equal but overwhelmingly in favor of the nuclear genome, which controls mtDNA maintenance, replication and integrity. Pathogenic mutations in nuclear genes affecting mtDNA maintenance lead to two groups of mitochondrial diseases, characterized by mtDNA depletion or multiple mtDNA deletions. Their mendelian genetic origin shares in common phenotypical variegated expression with mtDNA-related diseases, due to the "threshold effect" of mtDNA damage.

The concept of mtDNA depletion was introduced in 1991 by Carlos Moraes, showing complete or partial mtDNA reduction in different tissues from severely affected infants [16]. At the same time, Eduardo Bonilla devised an immunochemical stain for mtDNA in contrast to bright nDNA to be applied in muscle biopsies [17].

Multiple nuclear genes are involved in controlling mitochondrial nucleic acid biosynthesis and the intramitochondrial pool of deoxynucleoside triphosphates (dTNPs), the building blocks of DNA.

Mutations in the DGUOK gene encoding deoxyguanosine kinase were described in Israel, causing a severe hepatocerebral syndrome with neonatal liver failure, nystagmus, and hypotonia [18].

Mutations in the TK2 gene encoding thymidine kinase 2 are among the most common causes of mitochondrial depletion syndrome, with about 200 patients that have been reported by two groups, Hirano's and Wang's $[19,20]$. Most of the patients with TK2 mutations have an infantile onset form, presenting at or soon after birth with generalized weakness, respiratory insufficiency, and death at 1 to 3 years of age. Severe skeletal muscle mtDNA depletion is commonly observed.

Lately, Michio Hirano and Caterina Garone have developed a life-saving therapeutic approach for these infants. The therapy provided oral deoxynucleosides (the substrates of the TK2 enzyme) and showed efficacy in ameliorating mtDNA depletion and increased lifespan in mice [21,22]. Up to today, this treatment has been used in 16 patients worldwide under compassionate use, the exiting results obtained in this cohort will lead to a forthcoming clinical trial.

Mutations in the SUCLA2 gene encoding ADP-forming succinyl-CoA synthase usually cause severe infantile encephalomyopathies [23] but they may present in childhood with psychomotor delay, deafness, myopathy, ataxia, and chorea [24]. Mutations in the SUCLG1 gene encoding succinyl-CoA ligase have been associated with infantile hepatocerebral LS-like syndrome [25].

Mutations in the RRM2B gene encoding p53-inducible ribonucleoside reductase subunit 2B caused severe infantile disease, with hypotonia, tubulopathy, seizures, respiratory distress, diarrhea, and lactic acidosis [26] but application of whole exome sequencing (WES) has revealed unusual late-onset cases with PEO [27] or KSS [28], and a case with mitochondrial neurogastrointestinal encephalomyopathy (MNGIE syndrome) [29].

Mutations in the TYMP gene encoding thymidine phosphorylase (TP), identified by Michio Hirano [30], were associated with the severe syndrome of MNGIE. The syndrome usually affects 
young adults with intestinal problems (increased borborygmi, intestinal pseudoobstruction, diarrhea), PEO, severe peripheral neuropathy (axonal or demyelinating), and leukoencephalopathy. The disease course is severe, evolving in pronounced cachexia and early death. The pathogenesis of MNGIE is attributed to excessive accumulation of two toxic compounds, thymidine and deoxyuridine, causing mtDNA alterations (depletion, multiple deletions, and site-specific point mutations, isolated or in combination) [31].

Michio Hirano introduced a useful, if risky, therapy for patients with devastating MNGIE syndrome. It consists in allogeneic hematopoietic stem cell transplant (AHSCT, i.e., bone marrow transplantation), which showed in an international clinical trial to be able to detoxify the body from thymidine and deoxyuridine, alleviating neuropathy, and increasing body weight [32].

Massimo Zeviani's group [33] discovered mutations in the MPV17 gene encoding a protein in the inner mitochondrial membrane (IMM) of uncertain significance, causing a severe infantile hepatocerebral syndrome. To our recognition, we attributed MPV17 mutations to the Navajo neurohepatopathy $(\mathrm{NNH})$, an endemic disease in the Southwestern US, characterized by childhood neuropathy, acral mutilation, corneal scarring or ulceration, liver failure, and CNS demyelination [34].

Impairing mtDNA replication may cause severe mtDNA depletion, exemplified by AlpersHuttenlocher syndrome (AHS) due to mutations in the POLG gene encoding polymerase gamma [35]. A triad of refractory seizures, psychomotor regression, and liver disease in children characterizes AHS. Patients with AHS do not survive long and are particularly vulnerable to administration of valproic acid (VPA) therapy.

However, innumerable mutations throughout the POLG gene- even a few heterozygous-cause a variety of phenotypes, including PEO-plus, sensory ataxic neuropathy, dysarthria, and ophthalmoparesis (SANDO), mitochondrial recessive ataxia syndrome (MIRAS), and PD, all reviewed by Dr. William Copeland [36].

Multiple mtDNA deletions were first attributed to mendelian genetics by Massimo Zeviani and Stefano DiDonato [15] and a woman that was described by Suomalainen, manifesting PEO and psychiatric disorder, carried multiple deletions of mtDNA in her muscle, brain, and liver [37]. In short sequence, multiple mtDNA deletions were related to the gene ANT1 (ADP-ATP translocase) that was identified mutant in a Finnish family with autosomal dominant PEO [38]. Only few cases of autosomal dominant $\mathrm{PEO}$ have been recognized as caused by heterozygous mutations of the renamed SLC25A4 gene, which encodes the ADP-ATP translocase. However, the relevance of nuclear genes encoding mitochondrial carriers (MC) has been recently increased because of the growing number of mutations discovered in MC genes that lead to MC-associated diseases. Such number will likely increase further, particularly because the role of more than 20 human genes of the SLC25 family remains to be identified [39].

Mutations in the gene TWNK (or PEO) encoding the helicase Twinkle have been widely reported in families with autosomal dominant PEO [40] plus cardiomyopathy [41]. A frequent presentation of recessive TWNK mutations is infantile onset spinocerebellar ataxia (IOSCA) [42,43].

Mutations in the TK2 gene show-beside infantile-onset myopathy-later-onset presentations with multiple mtDNA deletions in skeletal muscle [19,44]. A case of my friend Darryl De Vivo was puzzling for typical SMA (Spinal Muscular Atrophy) and mitochondrial myopathy, showing childhood mtDNA depletion and multiple deletions encephalomyopathy [45]. There were several adults with PEO-plus and both childhood- and late-onset patients with TK2 gene mutations, who responded to oral deoxynucleoside therapy [22].

An unexpected adult with PEO-plus was affected with MPV17 gene mutations [46] and adult-onset autosomal dominant or recessive PEO-plus was reported in patients with mutations in the RRM2B gene [27-29], and in patients with DGUOK gene mutations [47].

Finally, mutations in the POLG2 gene, encoding the accessory dimeric subunit POLG2, enhancing binding to DNA, cause adult-onset dominant PEO [48] although we have recently found a homozygous POLG2 gene mutation causing fatal infantile hepatic failure with mtDNA depletion [49] (Table 1). 
Table 1. Intergenomic defects. Summary of multiple mendelian genetic defects affecting mtDNA integrity, causing - in various combinations-mtDNA depletion and mtDNA multiple deletions. Acronyms are explained in the text.

\begin{tabular}{ccc}
\hline Gene & mtDNA Depletion & mtDNA Multiple Deletions \\
\hline DGUOK & Hepato-cerebral syndrome & Adult-onset PEO \\
TK2 & Lethal infantile myopathy & Later-onset myopathies \\
SUCLA2 & Infantile encephalomyopathy & Later-onset movement disorder \\
SUCLG1 & Hepato-cerebral syndrome & \multicolumn{2}{c}{ Adult-onset PEO; KSS; MNGIE } \\
RRM2B & Infantile encephalomyopathy & Adult \\
TYMP & \multicolumn{2}{c}{ MNGIE } \\
MPV17 & Hepato-cerebral syndrome; NNH & \multicolumn{2}{c}{ Adult-onset PEO } \\
POLG & Alpers-Huttenlocher syndrome & Adult-onset PEO; SANDO; MIRAS; PD \\
POLG2 & Fatal infantile liver failure & \multicolumn{2}{c}{ Adult-onset PEO } \\
TWNK & - & AD PEO; IOSCA \\
ANT1 & - & Adult-onset PEO, dementia \\
OPA1 & DOA & Adult PEO-plus \\
\hline
\end{tabular}

Recent evidences also support a role for mtDNA damage and the related oxidative stress in the pathogenesis of atherosclerosis and vascular diseases. In fact, mtDNA oxidative damage is present at early stages of atherosclerosis and might promote the onset/progression of the disease because of its effects on mitochondrial and whole cell metabolism [50]. Also, the onset of vascular diseases appears related to the presence of genomic and mtDNA damage [51] and this is a further indication of the relevance that mtDNA alterations, even when not involving sequence mutations, might have for multifactorial diseases as many among the age-related diseases. More recently, studies involving sequencing of mtDNA regions from blood leukocytes of a large cohort of subjects have demonstrated the positive association of five specific mtDNA mutations with the incidence of carotid atherosclerosis suggesting that such mutations might be used to assess the predisposition to the disease [52]. Some mtDNA mutations from the most updated list of mutations potentially involved in atherosclerosis' pathogenetic mechanisms [53] are presently under experimental test to verify their effective role in the disease's onset. In fact, the creation of cybrids carrying different heteroplasmic levels of two mtDNA mutations, one associated with the presence and the other with the absence of atherosclerosis [54], will allow to thoroughly investigate the occurrence and the development of atherosclerosis in a quite simple cell model. This is the ultimate chronological step, but certainly not the last one along the pathway leading to the progressive understanding of the relevance of mtDNA mutations for monogenic as well as polygenic diseases.

\section{Conclusions}

This is my brief historical perspective on the discovery of autonomous pathogenic mtDNA mutations and of the related mendelian pathologies altering mtDNA integrity.

From the initial reports dating back to 1988, a long path has been followed with unexpected discoveries that opened an avenue leading to the always more detailed description of the newly identified mitochondrial pathologies as well as to a more comprehensive understanding of the crucial role of mitochondria inside cells, able also to send retrograde stress signals, which impinge on expression of nuclear genome and whole cell responses.

Conflicts of Interest: The author declares no conflict of interest. 


\section{Abbreviations}

$\begin{array}{ll}\text { mtDNA } & \text { mitochondrial DNA } \\ \text { Cytb } & \text { Cytochrome b gene } \\ \text { COX } & \text { cytochrome c oxidase } \\ \text { SDH } & \text { succinate dehydrogenase } \\ \text { IMM } & \text { inner mitochondrial membrane } \\ \text { PD } & \text { Parkinson's Disease }\end{array}$

\section{References}

1. Holt, I.J.; Harding, A.E.; Morgan-Hughes, J.A. Deletions of muscle mitochondrial DNA in patients with mitochondrial myopathies. Nature 1988, 331, 717-719. [CrossRef] [PubMed]

2. Wallace, D.C.; Singh, G.; Lott, M.T.; Hodge, J.A.; Schurr, T.G.; Lezza, A.M.; Elsas, L.J., 2nd; Nikoskelainen, E.K. Mitochondrial DNA mutation associated with Leber's hereditary optic neuropathy. Science 1988, 242, 1427-1430. [CrossRef] [PubMed]

3. Zeviani, M.; Moraes, C.T.; DiMauro, S.; Nakase, H.; Bonilla, E.; Schon, E.A.; Rowland, L.P. Deletions of mitochondrial DNA in Kearns-Sayre syndrome. Neurology 1988, 38, 1339-1346. [CrossRef] [PubMed]

4. DiMauro, S.; Schon, E.A. Mitochondrial respiratory-chain diseases (Mechanisms of Disease). N. Engl. J. Med. 2003, 348, 2656-2668. [CrossRef] [PubMed]

5. DiMauro, S.; Schon, E.A.; Carelli, V.; Hirano, M. The clinical maze of mitochondrial neurology. Nat. Rev. Neurol. 2013, 9, 429-444. [CrossRef] [PubMed]

6. Andreu, A.L.; Hanna, M.G.; Reichmann, H.; Bruno, C.; Penn, A.S.; Tanji, K.; Pallotti, F.; Iwata, S.; Bonilla, E.; Lach, B.; et al. Exercise intolerance due to mutations in the cytochrome $b$ gene of mitochondrial DNA. N. Engl. J. Med. 1999, 341, 1037-1044. [CrossRef] [PubMed]

7. Giles, R.E.; Blanc, H.; Cann, H.M.; Wallace, D.C. Maternal inheritance of human mitochondrial DNA. Proc. Natl. Acad. Sci. USA 1980, 77, 6715-6719. [CrossRef] [PubMed]

8. Chinnery, P.F.; DiMauro, S.; Shanske, S.; Schon, E.A.; Zeviani, M.; Mariotti, C.; Carrara, F.; Lombes, A.; Laforet, P.; Ogier, H.; et al. Risk of developing a mitochondrial DNA deletion disorder. Lancet 2004, 364, 592-596. [CrossRef]

9. Luo, S.; Valencia, C.A.; Zhang, J.; Lee, N.C.; Slone, J.; Gui, B.; Wang, X.; Li, Z.; Dell, S.; Brown, J.; et al. Biparental Inheritance of Mitochondrial DNA in Humans. Proc. Natl. Acad. Sci. USA 2018, 115, 13039-13044. [CrossRef] [PubMed]

10. Tanji, K.; Bonilla, E. Optical imaging techniques (histochemical, immunohistochemical, and in situ hybridization staining methods) to visualize mitochondria. Methods Cell Biol. 2007, 80, 135-154. [CrossRef] [PubMed]

11. Borthwick, G.M.; Taylor, R.W.; Walls, T.J.; Tonska, K.; Taylor, G.A.; Shaw, P.J.; Ince, P.G.; Turnbull, D.M. Motor neuron disease in a patient with a mitochondrial tRNAIle mutation. Ann. Neurol. 2006, 59, 570-574. [CrossRef] [PubMed]

12. Moraes, C.T.; Ciacci, F.; Bonilla, E.; Jansen, C.; Hirano, M.; Rao, N.; Lovelace, R.E.; Rowland, L.P.; Schon, E.A.; DiMauro, S. Two novel pathogenic mitochondrial DNA mutations affecting organelle number and protein synthesis. Is the tRNA (Leu(UUR)) gene an etiologic hot spot? J. Clin. Investig. 1993, 92, 2906-2915. [CrossRef] [PubMed]

13. Karadimas, C.L.; Greenstein, P.; Sue, C.M.; Joseph, J.T.; Tanji, K.; Haller, R.G.; Taivassalo, T.; Davidson, M.M.; Shanske, S.; Bonilla, E.; et al. Recurrent myoglobinuria due to a nonsense mutation in the COX I gene of mitochondrial DNA. Neurology 2000, 55, 644-649. [CrossRef] [PubMed]

14. King, M.P.; Attardi, G. Human cells lacking mtDNA: Repopulation with exogenous mitochondria by complementation. Science 1989, 246, 500-503. [CrossRef] [PubMed]

15. Zeviani, M.; Servidei, S.; Gellera, C.; Bertini, E.; DiMauro, S.; DiDonato, S. An autosomal dominant disorder with multiple deletions of mitochondrial DNA starting at the D-loop region. Nature 1989, 339, 309-311. [CrossRef] [PubMed]

16. Moraes, C.T.; Shanske, S.; Tritschler, H.J.; Aprille, J.R.; Andreetta, F.; Bonilla, E.; Schon, E.A.; DiMauro, S. mtDNA depletion with variable tissue expression: A novel genetic abnormality in mitochondrial diseases. Am. J. Hum. Genet. 1991, 48, 492-501. [PubMed] 
17. Tritschler, H.J.; Andreetta, F.; Moraes, C.T.; Bonilla, E.; Arnaudo, E.; Danon, M.J.; Glass, S.; Zelaya, B.M.; Vamos, E.; Telerman-Toppet, N.; et al. Mitochondrial myopathy of childhood associated with depletion of mitochondrial DNA. Neurology 1992, 42, 209-217. [CrossRef] [PubMed]

18. Mandel, H.; Szargel, R.; Labay, V.; Elpeleg, O.; Saada, A.; Shalata, A.; Anbinder, Y.; Berkowitz, D.; Hartman, C.; Barak, M.; et al. The deoxyguanosine kinase gene is mutated in individuals with depleted hepatocerebral mitochondrial DNA. Nat. Genet. 2001, 29, 337-341. [CrossRef] [PubMed]

19. Garone, C.; Taylor, R.W.; Nascimento, A.; Poulton, J.; Fratter, C.; Dominguez-Gonzalez, C.; Evans, J.C.; Loos, M.; Isohanni, P.; Suomalainen, A.; et al. Retrospective natural history of thymidine kinase 2 deficiency. J. Med. Genet. 2018, 55, 515-521. [CrossRef] [PubMed]

20. Wang, J.; Kim, E.; Dai, H.; Stefans, V.; Vogel, H.; Al Jasmi, F.; Schrier Vergano, S.A.; Castro, D.; Bernes, S.; Bhambhani, V.; et al. Clinical and molecular spectrum of thymidine kinase 2-related mtDNA maintenance defect. Mol. Genet. Metab. 2018, 124, 124-130. [CrossRef] [PubMed]

21. Lopez-Gomez, C.; Levy, R.J.; Sanchez-Quintero, M.J.; Juanola-Falgarona, M.; Barca, E.; Garcia-Diaz, B.; Tadesse, S.; Garone, C.; Hirano, M. Deoxycytidine and Deoxythymidine Treatment for Thymidine Kinase 2 Deficiency. Ann. Neurol. 2017, 81, 641-652. [CrossRef] [PubMed]

22. Hirano, M.; Emmanuele, V.; Quinzii, C.M. Emerging therapies for mitochondrial diseases. Essays Biochem. 2018, 62, 467-481. [CrossRef] [PubMed]

23. Elpeleg, O.; Miller, C.; Hershkovitz, E.; Bitner-Glindzicz, M.; Bondi-Rubinstein, G.; Rahman, S.; Pagnamenta, A.; Eshhar, S.; Saada, A. Deficiency of the ADP-forming succinyl-CoA synthase activity is associated with encephalomyopathy and mitochondrial DNA depletion. Am. J. Hum. Genet. 2005, 76, 1081-1086. [CrossRef] [PubMed]

24. Garone, C.; Gurgel-Giannetti, J.; Sanna-Cherchi, S.; Krishna, S.; Naini, A.; Quinzii, C.M.; Hirano, M. A Novel SUCLA2 Mutation Presenting as a Complex Childhood Movement Disorder. J. Child. Neurol. 2017, 32, $246-250$. [CrossRef] [PubMed]

25. Van Hove, J.L.; Saenz, M.S.; Thomas, J.A.; Gallagher, R.C.; Lovell, M.A.; Fenton, L.Z.; Shanske, S.; Myers, S.M.; Wanders, R.J.; Ruiter, J.; et al. Succinyl-CoA ligase deficiency: A mitochondrial hepatoencephalomyopathy. Pediatr. Res. 2010, 68, 159-164. [CrossRef] [PubMed]

26. Bornstein, B.; Area, E.; Flanigan, K.M.; Ganesh, J.; Jayakar, P.; Swoboda, K.J.; Coku, J.; Naini, A.; Shanske, S.; Tanji, K.; et al. Mitochondrial DNA depletion syndrome due to mutations in the RRM2B gene. Neuromuscul. Disord. 2008, 18, 453-459. [CrossRef] [PubMed]

27. Takata, A.; Kato, M.; Nakamura, M.; Yoshikawa, T.; Kanba, S.; Sano, A.; Kato, T. Exome sequencing identifies a novel missense variant in RRM2B associated with autosomal recessive progressive external ophthalmoplegia. Genome Biol. 2011, 12, R92. [CrossRef] [PubMed]

28. Pitceathly, R.D.; Fassone, E.; Taanman, J.W.; Sadowski, M.; Fratter, C.; Mudanohwo, E.E.; Woodward, C.E.; Sweeney, M.G.; Holton, J.L.; Hanna, M.G.; et al. Kearns-Sayre syndrome caused by defective R1/p53R2 assembly. J. Med. Genet. 2011, 48, 610-617. [CrossRef] [PubMed]

29. Shaibani, A.; Shchelochkov, O.A.; Zhang, S.; Katsonis, P.; Lichtarge, O.; Wong, L.J.; Shinawi, M. Mitochondrial neurogastrointestinal encephalopathy due to mutations in RRM2B. Arch. Neurol. 2009, 66, 1028-1032. [CrossRef] [PubMed]

30. Nishino, I.; Spinazzola, A.; Hirano, M. Thymidine phosphorylase gene mutations in MNGIE, a human mitochondrial disorder. Science 1999, 283, 689-692. [CrossRef] [PubMed]

31. Nishigaki, Y.; Marti, R.; Hirano, M. ND5 is a hot-spot for multiple atypical mitochondrial DNA deletions in mitochondrial neurogastrointestinal encephalomyopathy. Hum. Mol. Genet. 2004, 13, 91-101. [CrossRef] [PubMed]

32. Halter, J.P.; Michael, W.; Schüpbach, M.; Mandel, H.; Casali, C.; Orchard, K.; Collin, M.; Valcarcel, D.; Rovelli, A.; Filosto, M.; et al. Allogeneic haematopoietic stem cell transplantation for mitochondrial neurogastrointestinal encephalomyopathy. Brain 2015, 138 Pt 10, 2847-2858. [CrossRef] [PubMed]

33. Spinazzola, A.; Viscomi, C.; Fernandez-Vizarra, E.; Carrara, F.; D’Adamo, P.; Calvo, S.; Marsano, R.M.; Donnini, C.; Weiher, H.; Strisciuglio, P.; et al. MPV17 encodes an inner mitochondrial membrane protein and is mutated in infantile hepatic mitochondrial DNA depletion. Nat. Genet. 2006, 38, 570-575. [CrossRef] [PubMed] 
34. Karadimas, C.L.; Vu, T.H.; Holve, S.A.; Chronopoulou, P.; Quinzii, C.; Johnsen, S.D.; Kurth, J.; Eggers, E.; Palenzuela, L.; Tanji, K.; et al. Navajo neurohepatopathy is caused by a mutation in the MPV17 gene. Am. J. Hum. Genet. 2006, 79, 544-548. [CrossRef] [PubMed]

35. Nguyen, K.V.; Ostergaard, E.; Ravn, S.H.; Balslev, T.; Danielsen, E.R.; Vardag, A.; McKiernan, P.J.; Gray, G.; Naviaux, R.K. POLG mutations in Alpers syndrome. Neurology 2005, 65, 1493-1495. [CrossRef] [PubMed]

36. Wong, L.J.; Naviaux, R.K.; Brunetti-Pierri, N.; Zhang, Q.; Schmitt, E.S.; Truong, C.; Milone, M.; Cohen, B.H.; Wical, B.; Ganesh, J.; et al. Molecular and clinical genetics of mitochondrial diseases due to POLG mutations. Hum. Mutat. 2008, 29, E150-E172. [CrossRef] [PubMed]

37. Suomalainen, A.; Majander, A.; Haltia, M.; Somer, H.; Lonnqvist, J.; Savontaus, M.L.; Peltonen, L. Multiple deletions of mitochondrial DNA in several tissues of a patient with severe retarded depression and familial progressive external ophthalmoplegia. J. Clin. Investig. 1992, 90, 61-66. [CrossRef] [PubMed]

38. Kaukonen, J.; Juselius, J.K.; Tiranti, V.; Kyttälä, A.; Zeviani, M.; Comi, G.P.; Keränen, S.; Peltonen, L.; Suomalainen, A. Role of adenine nucleotide translocator 1 in mtDNA maintenance. Science 2000, 289, 782-785. [CrossRef] [PubMed]

39. Palmieri, F. Mitochondrial transporters of the SLC25 family and associated diseases: A review. J. Inherit. Metab. Dis. 2014, 37, 565-575. [CrossRef] [PubMed]

40. Paradas, C.; Camano, P.; Otaegui, D.; Oz, O.; Emmanuele, V.; DiMauro, S.; Hirano, M. Longitudinal clinical follow-up of a large family with the R357P Twinkle mutation. JAMA Neurol. 2013, 70, 1425-1428. [CrossRef] [PubMed]

41. Hong, D.; Bi, H.; Yao, S.; Wang, Z.; Yuan, Y. Clinical phenotype of autosomal dominant progressive external ophthalmoplegia in a family with a novel mutation in the C10orf2 gene. Muscle Nerve 2010, 41, 92-99. [CrossRef] [PubMed]

42. Nikali, K.; Suomalainen, A.; Saharinen, J.; Kuokkanen, M.; Spelbrink, J.N.; Lonnqvist, T.; Peltonen, L.L. Infantile onset spinocerebellar ataxia is caused by recessive mutations in mitochondrial proteins Twinkle and Twinky. Hum. Mol. Genet. 2005, 14, 2981-2990. [CrossRef] [PubMed]

43. Hakonen, A.H.; Goffart, S.; Marjavaara, S.; Paetau, A.; Cooper, H.; Mattila, K.; Lampinen, M.; Sajantila, A.; Lönnqvist, T.; Spelbrink, J.N.; et al. Infantile-onset spinocerebellar ataxia and mitochondrial recessive ataxia syndrome are associated with neuronal complex I defect and mtDNA depletion. Hum. Mol. Genet. 2008, 17, 3822-3835. [CrossRef] [PubMed]

44. Paradas, C.; Gutierrez Rios, P.; Rivas, E.; Carbonell, P.; Hirano, M.; DiMauro, S. TK2 mutation presenting as indolent myopathy. Neurology 2013, 80, 504-506. [CrossRef] [PubMed]

45. Pons, R.; Andreetta, F.; Wang, C.H.; Vu, T.H.; Bonilla, E.; DiMauro, S.; De Vivo, D.C. Mitochondrial myopathy simulating spinal muscular atrophy. Pediatr. Neurol. 1996, 15, 153-158. [CrossRef]

46. Garone, C.; Rubio, J.C.; Calvo, S.E.; Naini, A.; Tanji, K.; Dimauro, S.; Mootha, V.K.; Hirano, M. MPV17 Mutations Causing Adult-Onset Multisystemic Disorder with Multiple Mitochondrial DNA Deletions. Arch. Neurol. 2012, 69, 1648-1651. [CrossRef] [PubMed]

47. Ronchi, D.; Garone, C.; Bordoni, A.; Gutierrez Rios, P.; Calvo, S.E.; Ripolone, M.; Ranieri, M.; Rizzuti, M.; Villa, L.; Magri, F.; et al. Next-generation sequencing reveals DGUOK mutations in adult patients with mitochondrial DNA multiple deletions. Brain 2012, 135 Pt 11, 3404-3415. [CrossRef] [PubMed]

48. Longley, M.J.; Clark, S.; Man, C.Y.; Hudson, G.; Durham, S.E.; Taylor, R.W.; Nightingale, S.; Turnbull, D.M.; Copeland, W.C.; Chinnery, P.F. Mutant POLG2 disrupts DNA polymerase gamma subunits and causes progressive external ophthalmoplegia. Am. J. Hum. Genet. 2006, 78, 1026-1034. [CrossRef] [PubMed]

49. Varma, H.; Faust, P.L.; Iglesias, A.D.; Lagana, S.M.; Wou, K.; Hirano, M.; DiMauro, S.; Mansukani, M.M.; Hoff, K.E.; Nagy, P.L.; et al. Whole exome sequencing identifies a homozygous POLG2 missense variant in an infant with fulminant hepatic failure and mitochondrial DNA depletion. Eur. J. Med. Genet. 2016, 59, 540-545. [CrossRef] [PubMed]

50. Yu, E.P.; Bennett, M.R. The role of mitochondrial DNA damage in the development of atherosclerosis. Free Radic. Biol. Med. 2016, 100, 223-230. [CrossRef] [PubMed]

51. Uryga, A.; Gray, K.; Bennett, M. DNA Damage and Repair in Vascular Disease. Annu. Rev. Physiol. 2016, 78, 45-66. [CrossRef] [PubMed]

52. Sazonova, M.A.; Sinyov, V.V.; Ryzhkova, A.I.; Galitsyna, E.V.; Khasanova, Z.B.; Postnov, A.Y.; Yarygina, E.I.; Orekhov, A.N.; Sobenin, I.A. Role of Mitochondrial Genome Mutations in Pathogenesis of Carotid Atherosclerosis. Oxid. Med. Cell. Longev. 2017, 2017, 6934394. [CrossRef] [PubMed] 
53. Volobueva, A.; Grechko, A.; Yet, S.F.; Sobenin, I.; Orekhov, A. Changes in Mitochondrial Genome Associated with Predisposition to Atherosclerosis and Related Disease. Biomolecules 2019, 9, 377. [CrossRef] [PubMed]

54. Sazonova, M.A.; Sinyov, V.V.; Ryzhkova, A.I.; Sazonova, M.D.; Khasanova, Z.B.; Shkurat, T.P.; Karagodin, V.P.; Orekhov, A.N.; Sobenin, I.A. Creation of Cybrid Cultures Containing mtDNA Mutations m.12315G>A and m.1555G>A, Associated with Atherosclerosis. Biomolecules 2019, 9, 499. [CrossRef] [PubMed]

(C) 2019 by the author. Licensee MDPI, Basel, Switzerland. This article is an open access article distributed under the terms and conditions of the Creative Commons Attribution (CC BY) license (http://creativecommons.org/licenses/by/4.0/). 